\title{
Between Heimat and Schubsystem: Walking the Homeless to Death in Early Modern Austria
}

\author{
Hermann Rebel
}

\begin{abstract}
Aвstract. Beginning with Ferdinand I's Polizeyordnung of 1552, the Habsburgs' state inserted itself into the regulation of welfare for the poor. To manage the homeless, there emerged after the 1720 s a state-driven but locally administered system (Schubsystem) of police surveillance to discover, arrest, and physically remove those without a provable birth place (or a ten-year residence in one place) to a to-be-determined Heimat, a "home" community declared responsible for their welfare. In practice, the system's specific self-contradictions and conflicted agendas, its brutalization of those who served it, its several social-relational and language figures that emerged as the actualizations of the state's vision, together placed a significant number of the homeless on forced marches toward indeterminate destinations until they collapsed and could be removed from the road to die "in the straw." The essay suggests that the interplay between Heimat and Schubsystem serves as a foreshadowing dimension in modern Austro-German history.
\end{abstract}

Der Habsburger Staat schaltete sich, beginnend mit Ferdinand des Ersten Polizeyordnung (1552), in die Regelung der Armenfürsorge ein. Um sich der Zahl der Heimatlosen zu bemächtigen, entstand nach 1720 das sogenannte Schubsystem, eine vom Staat dirigierte, aber örtlich geregelte Polizeiüberwachung mit der Aufgabe, alle ohne nachweisbaren Geburtsort oder zehnjährigen Aufenthalt an einem Ort aufzuspüren, in Haft zu nehmen und an eine festzustellende "Heimatgemeinde" mit Wohlfahrtsverantwortung abzutransportieren. In der Praxis und auf Grund der Widersprüche und Konflikte des Systems sowie der Brutalisierung jener, die dem System dienten, und dazu noch der mehrfachen Gesellschafts- und Redewendungen, welche die Vorstellungen des Staats realisierten, wurde eine bedeutende Anzahl der Heimatlosen zu Gewaltmärschen ohne Bestimmungsort gezwungen, bis sie zusammenbrachen und von der Strasse entfernt "im Stroh" starben. Der Aufsatz legt nahe, dass das Zusammenspiel zwischen Heimat und Schubsystem als vorausahnende Dimension der modernen deutsch-österreichischen Geschichte wirkt.

$\mathrm{D}$ ANIEL Goldhagen's much-debated explanation of Germans' criminal imposition of the Holocaust on Europe's Jews was grounded in a culturally embedded German hatred for Jews, carried forward with varying degrees of intensity, itself unchanged for centuries by historical experience, until it was mobilized by the rise to political power of Nazi exterminism and was acted out in labor and death camps and in ad hoc, open-air sites where frontline perpetrators killed, willingly, millions of Jews. ${ }^{1}$ It does not diminish the central significance of Jewish victims to say that they were murdered alongside millions of non-Jews. One snag in any exclusive antisemitism narrative is what to do about those others who were also explicitly targeted in an

The first version of this essay was presented to Rhetorics of Culture: A Conference on Historical Anthropology in Honor of S. C. Humphreys at the University of Michigan in Ann Arbor, September 24-26, 1999. With thanks to the staff of the Landesarchiv in Linz, Upper Austria, and to the Harry Frank Guggenheim Foundation for generous research assistance. Thanks also to the anonymous reviewers of this journal for opening a different course for my argument.

${ }^{1}$ Daniel Jonah Goldhagen, Hitler's Willing Executioners: Ordinary Germans and the Holocaust (New York: Knopf, 1996); for early critiques of this argument, see Robert Shandley, ed., Unwilling Germans: The Goldhagen Debate (Minneapolis: University of Minnesota Press, 1998). 
arguably unique and unprecedented German escalation of mass murder. By taking up the exterminist aspects of this civilizational collapse, this article wants to explore the possibility of an alternative long-duration narrative that draws on a historical anthropology that does not require a transhistorical cultural formation and leaves room for an enlarged identification of victims, including victims of antisemitism. ${ }^{2}$

Beginning with his title, Goldhagen is concerned throughout to point repeatedly to "ordinary Germans" and their will-formation for the killing. Christopher Browning also echoes this ordinariness of the perpetrators in his examination of comparable mass murders taking place elsewhere under the General Plan for the East. ${ }^{3}$ For both analysts, ordinariness is a quality necessary for each of their, at first sight, divergent explanations for perpetrators' motivations. Ordinariness allows Goldhagen to characterize "the Germans" according to a model from cognitive anthropology by which one can purport to scale groups' socially acquired performance models as these are embedded in a continuously reproduced everyday culture, focusing in particular on the mobilizing capacity of a culture's central "stable source metaphor." ${ }_{4}$ It is the moral force of this "thick concept" formation that authorizes (and thereby explains) even the most extreme actions. ${ }^{5}$ Browning, by contrast, engages more directly with the perpetrators' experiences to probe the existential, situational dimensions of their willingness to murder. He draws from Stanley Milgram's famous "obedience" experiments a social-psychological model by which the police battalion shooters, socialized into a "deeply ingrained behavior tendency" to comply with orders from hierarchic superiors and subject to a barrage of motivating (and ethically implicating) manipulations by those superiors, in most cases conformed, were loyal to their group, and overcame personal resistance in what Browning sees as Primo Levi's "zone of ambiguity which radiates out from regimes based on terror and obsequiousness." 6

Both analyses carry weight in that they bring to light important and detailed historical facts, historical in the sense that they are of the past and are brought into currently active memory. Moreover, both explanations for German perpetrators' motivations were undoubtedly in play in the historical moment and cannot be discounted, let alone displaced, by the supplemental reading this article seeks to develop. They do contain, however, serious weaknesses, such as when Goldhagen overplays an ahistorical cultural prime directive card, or when Browning transposes the authority of scientists in a laboratory setting to actual military commands in the killing fields. It has to be said that, from a historian's point of view, both authors have performed a circular sleight-of-hand. This is not only because Jew-hating Germans killed Jews or obedient Germans obeyed; it is rather that historical circumstances and events drawn from archival materials have

\footnotetext{
${ }^{2}$ There is no disputing the fact that the Nazi Party's program explicitly excluded Jews from citizenship and that this exclusion became a foundational legal source for the Nazis' exterminist treatment of Jews. See Bernd Rüthers, Entartetes Recht. Rechtslehren und Kronjuristen im Dritten Reich (Munich: dtv, 1994), 29. On historical anthropology, see Don Kalb and Herman Tak, eds., Critical Junctions: Anthropology and History beyond the Cultural Turn (New York: Berghahn, 2005).

${ }^{3}$ Christopher Browning, Ordinary Men: Reserve Police Battalion 101 and the Final Solution in Poland (New York: Harper Collins, 1992); idem, Nazi Policy, Jewish Workers, German Killers (Cambridge: Cambridge University Press, 2000).

${ }^{4}$ Goldhagen refers to Dorothy Holland and Naomi Quinn, eds., Cultural Models in Language and Thought (Cambridge: Cambridge University Press, 1987) and, in particular in that volume, to Roy D'Andrade, "A Folk Model of the Mind," according to which "the culturally shared cognitive model of the mind can reproduce itself over centuries." See Goldhagen, Hitler's Willing Executioners, 27-48, esp. 41, 487n.44. For alternatives to D'Andrade's folk-mind modeling, see Hermann Rebel, When Women Held the Dragon's Tongue and Other Essays in Historical Anthropology (New York: Berghahn, 2010).

${ }^{5}$ This term derives from Bernard Williams. See, e.g., his chapter "The Scientific and the Ethical," in Contemporary Materialism ed. John Moser and J.D. Trout (New York: Routledge, 1996), 279-96. The term could well serve as a kind of collective noun to cover the culturally central directives sought by the cognitivist schools and their antecedents in symbolic actionist and so-called "thick description" anthropologies by Gilbert Ryle, Clifford Geertz, Sherry Ortner, William H. Sewell, and others.

${ }^{6}$ Brown, Ordinary Men, 171-75, 184-87.
} 
been written, respectively, in languages of cognitive anthropology and behaviorist social psychology to demonstrate hypotheses that are not in themselves historical but yet are represented, in turn, as historical explanations. No histories, no prior evolutions appear from which these police battalions can emerge. Browning begins with the latter's adaptation to Heinrich Himmler's reorganization of German police forces but provides no sense of what "German police" means in historical terms. Goldhagen, meanwhile, claims a cultural imperative that ebbs and flows in time but remains outside of history until it appears ex machina to prompt the police battalions' unprecedented killing orgy. Neither explanation takes us beyond a broadened intentionalism (Goldhagen) or an ever more narrowly focused functionalism (Browning), which is to say that both remain locked in a debate that has, over its long life, become too attenuated to be satisfying.

Both authors' archival reporting nevertheless contains openings for suggesting a different kind of investigation into the provenances of these defining events of the Holocaust. One such opportunity appears in Goldhagen's moving chapters depicting the forced death marches of the last survivors of the collapsed camp system. ${ }^{7}$ The aimlessness of the marchers' zigzagging routespurportedly aimed at finding work that everyone knew was not there to be found-and their deaths from hunger, exposure, and outright murder in pursuit of this lie contain what may be seen as a figural fulfillment of prior moments that one can recognize from archival investigation into the Austro-German subject population's historical experience.

This article explores an earlier and arguably associated "death-march" figure as it appeared under the Habsburgs' absolute state. The latter's interlocking central and provincial police authorities claimed to secure a native homeland, a Heimat, by returning those deemed not to belong there to their proper places via marching routes determined by the so-called Schubsystem. Cultural cognitivism could easily make a perpetually sentimentalized Heimat appear as a kind of extra-historical and unchanging cultural value with moral force. The intention here, however, is not to imply a naively culturalist defense-of-the-homeland motive in a long-duration account of the currents streaming into the Holocaust. The intention, instead, is to show Heimat in action, entwined as a social and linguistic figuration with historical moments, with actual laws, regulations, and practices adjusted to evolving purposes and circumstances. Moreover, having, as a figure-in-language, to represent both itself and something else, it perforce contains a duplexity of meaning, revealed here in its companion institutions of the $S c h u b$, so called to this day, where being found without a verifiable native place was an opening for an administered death.

\section{Pre-Figurations and Their Fulfillments}

A figural approach to framing historical investigations avoids prior culturalist or behaviorist conceptualizations in that it arises from the historian's recognition of repeated, homologous action and language figures taking shape in historical formations and events across interwoven passages of time. This kind of recognition includes figures of speech that reveal the perceived models and textures of "reality" that served to give meaning, in their own time, to the social formational figures under investigation. It is such figures' passages through time and memory that can offer a sense of foreshadowing, a perception of pre-figuration and figural fulfillment that is Eric Auerbach's theme in Mimesis. ${ }^{8}$ This is to say that witnessing the appearance, unfolding, and

\footnotetext{
${ }^{7}$ Goldhagen, Hitler's Willing Executioners, 327-71.

${ }^{8}$ Two stimulating expositions of figural reading in both literary and social analysis are Erich Auerbach, "Figura" (1938), reprinted in Time, History, and Literature: Selected Essays of Erich Auerbach, ed. James I. Porter, trans. Jane O. Newman (Princeton, NJ: Princeton University Press, 2014); idem, Mimesis: The Representation of Reality in Western Literature (Princeton, NJ: Princeton University Press, 1953). Also see Norbert Elias's early writings on figurations in Die höfische Gesellschaft (1933; repr., Frankfurt/Main: Suhrkamp, 1953); idem, What is Sociology? (London: Hutchison, 1978).
} 
articulations of historical figurations enables not directly causal but narrative linkages that offer insight into the provenances of events and actions for which prior figures may appear as foreshadowings, as pre-figurations pointing toward fulfillments to come in historical time. We can find one such recognition in Debórah Dwork's and Robert Jan van Pelt's Auschwitz: 1270 to the Present, in which they reproduce - expressly as such a "foreshadowing"- a passage written by a Jewish girl in 1912 about an experience at a German border crossing during the late 1890s in transit from Poland to the United States. ${ }^{9}$ From a present perspective, one can not help but see moments from the Holocaust-to-come in her account of the border police and the officials of the cordon sanitaire, whipping up a frenzied scene, herding people on the double through disinfection and medical procedures, through inspections and appraisals, that devalued and, by implication, verminized the herded. Her relief when it was over ("Oh so we really won't be murdered") is that of a child-survivor who has experienced a zone of mortal danger, the worst moments of which were then still below the horizon. The border agents she encountered would have included Schub police and, as this article will attempt to show, she was experiencing a moment of fulfillment of an earlier, lethal pre-figuration that made her dire recognition in the moment fully appropriate and her relief the only intelligent response.

As is the case with Goldhagen, this article also owes a debt to anthropologists, specifically to Eric Wolf and S.C. Humphreys, both adepts at figural recognition, whose writing not only helped the present author think about and arrange archival data into a tentatively coherent historical narrative, but whose sense of and capacity for figural outlining has a direct bearing on it. Wolf's explorations of various configurations and of their cultural implications that appear in peasant societies helped me see some of the determining legal, economic, and social logics (and contradictions) inside Austrian peasant family and household formations under the early modern state's restructuring of corporate and property relations, the latter resulting in a fundamental division of peasant families into a minority that inherited and could stay, and a majority that was disinherited and had to leave. ${ }^{10}$ This dispossession moment in an inherently conflicted family formation was at odds with the idealized, harmonious descriptions found in the historical literature, much of which was under the influence of Otto Brunner's version of the peasantry's household economy, the oikos ("the whole house"). ${ }^{11}$ In the course of tracking Brunner's peasant family model through his reading of the early modern neo-Stoics and of Helmhard von Hohberg, I found clarification in S.C. Humphreys's presentation of the successive appearances of a Greek oikos figure. Humphreys traces this figure through a range of settings: from Homeric warriors returning home to where their nurses recognized them and they had to redraw, with violence if necessary, the boundaries of their obligatory hospitality; to Hesiod's autarkic, smallholder firms of the hoplite society, where each competes with all and the boundaries of membership are ever more narrowly drawn; and on to Xenophon's oikos, a slave-managing rural household serving to sustain the politically obligated citizen returning to a well-managed rural idyll to recuperate from a decadent demos. ${ }^{12}$ Humphreys's readings reveal house economies, each one an idealized oikos, whose

\footnotetext{
${ }^{9}$ Mary Antin, The Promised Land (Boston: Houghton, 1912), 174, quoted in Debórah Dwork and Robert Jan van Pelt, Auschwitz: 1270 to the Present (New York: Norton, 1996), 52-54.

${ }^{10}$ Hermann Rebel, Peasant Classes: The Bureaucratization of Property and Family Relations under Early Habsburg Absolutism, 1511-1636 (Princeton, NJ: Princeton University Press, 1983).

${ }^{11}$ Otto Brunner, "Das 'ganze Haus' und die alteuropäische 'Ökonomik,"” in Neue Wege der Verfassungs- und Sozialgeschichte (Göttingen: Vandenhoeck \& Ruprecht, 1968). For the broader context of Brunner, see James van Horn Melton, "From Folk History to Structural History: Otto Brunner (1898-1982) and the Radical-Conservative Roots of German Social History," in Paths of Continuity: Central European Historiography from the 1939s to the 1950s, ed. Hartmut Lehmann and James van Horn Melton (Cambridge: Cambridge University Press, 1994).

${ }^{12}$ S.C. Humphreys, Anthropology and the Greeks (London: Routledge \& Kegan Paul, 1978).
} 
self-management in service to the polis necessarily generated conflicted acts, choices for inclusion and exclusion, to be absorbed by and concealed inside the private world of the home farm. ${ }^{13}$ This altogether contradicted the ostensibly harmonious family figure that the sixteenth- and seventeenthcentury neo-Stoics, and Otto Brunner in their wake, drew from a mostly Xenophonian classical model to transcribe to the ethos of an alleged "whole house" under corporatist absolutism.

This early modern, hegemonic idyll, the moral economy of the family farm, was in fact an oikos that had, as in Humphreys's perceived succession of Greek pre-figurations, little to do with family as such. The present article is an investigation into how the deeply conflicted and yet allegedly peaceful space of the Austrian home farm was replicated in its surrounding environment, in a peaceful and harmonious Heimat. It examines how this replication was legally enforced and guarded by the Schub police, who gathered the apparently homeless for purported resettlement, thereby shoring up a metonymic representation of "wholeness" by managing some of the destructive human consequences of the dispossessions and exclusions necessary to the peasantry's property and family relations, which were, in turn, intrinsic to the state's operations in early modern Austria's countryside. The argument that follows maintains that it was the enforcement of Heimat by the Schubsystem that prefigured both the terror Mary Antin experienced at that border in the late 1890s, as well as the willingness of the police battalion death squads to murder in the Holocaust.

\section{Institutions and Practices}

The few historical accounts in which Heimat and Schub appear together focus mainly on the authorities" "social control" interests and give weight neither to the social and legal formations that fed people into vagabondage in the first place, nor to the qualities and cumulative consequences of both the subjects' and the police agents' experiences in the system. Mack Walker's classic account of German "hometowns" guarding themselves against outsiders remains foundational, nevertheless. ${ }^{14}$ Many of those banished from legal jurisdictions and communes for criminal acts were destined, no doubt, to be gathered in by the Schub. ${ }^{15}$ Until recently, the passing references to the Schub that have appeared in the Austrian literature have been made in relation to this criminal justice nexus. ${ }^{16}$

In his recent monograph exploring wider aspects of the historical symbiosis of Heimat and Schub, however, Harald Wendelin expressly denies that it had a punitive (strafrechtliche) dimension and focuses instead on the central authorities" "spatial" penetration into the provinces to achieve a closed, bounded state (Flächenstaat). ${ }^{17}$ His is a "disciplining-for-modernity" model, following Gerhard Oestreich and Michel Foucault, in which the absolutist-corporate state expanded (here Wendelin follows Bronislaw Geremek) not for its own sake but rather for the public welfare.

\footnotetext{
${ }^{13}$ Ibid., 200-2; Hermann Rebel, "Reimaging the oikos: Austrian Cameralism in Its Social Formation," in Golden Ages, Dark Ages: Imagining the Past in Anthropology and History, ed. Jay O'Brien and William Roseberry (Berkeley: University of California Press, 1991).

${ }^{14}$ Mack Walker, German Hometowns: Community, State and General Estate, 1648-1871 (Ithaca, NY: Cornell University Press), 1971.

${ }^{15}$ Richard Evans, Rituals of Retribution: Capital Punishment in Germany (1600-1987) (Oxford: Oxford University Press, 1996), 31-32, 35; Jason Coy, Strangers and Misfits: Banishment, Social Control and Authority in Early Modern Germany (Leiden: Brill, 2008). In a class by itself, and an opening (in a Prussian context) toward what I have in mind here, is Alf Lüdtke, "Gemeinwohl". Polizei und "Festungspraxis". Staatliche Gewaltsamkeit und innere Verwaltung in Preußen, 1815-1850 (Göttingen: Vandenhoeck \& Ruprecht, 1982).

${ }^{16}$ For a view of workhouses and poor houses as Abschiebestationen for criminals and gangs, see Ernst Bruckmüller, Sozialgeschichte Österreichs (Vienna: Herold Verlag, 1985), 271; see also Hannes Stekl, Österreichs Zucht- und Arbeitshäuser, 1671-1920 (Vienna: Böhlau, 1978).

${ }^{17}$ Harald Wendelin, "Schub und Heimatrecht," in Grenze und Staat. Passwesen, Staatsbürgerschaft, Heimatrecht und Fremdengesetzgebung in der österreichischen Monarchie 1750-1867, ed. Waltraud Heindl and Edith Saurer (Vienna: Böhlau, 2000), 171-345.
} 
Heimat and Schub appear here as population-controlling instruments for social disciplining. His narrative has an inevitable, a positively necessary, quality that this reader has difficulty accepting. ${ }^{18}$ For Wendelin, this (for him unavoidable) process may have produced victims, but he denies that there were victimizers or perpetrators. Instead, there were only the "conquered-withoutconquerors," the "subject citizens," some of whom were necessary victims of what he sees, with Foucault, as a broadly shared "will-for-the-state." 19 This article shows, rather, that there were executors of the Schub at several levels of action, and that they set in motion the ethical and practical solutions for what to do about those without employment or shelter. These solutions not only ruled out possible alternatives but primarily served the interests of an emerging modus vivendi between central and local "authorities" (Obrigkeiten) at a cost not only in lives but also in an accumulation of official social violence and resulting agonies for which there is, so far, no means of historical accounting.

A foundational division in Austria's emerging absolutist-corporate state appeared in its very earliest moments when Ferdinand I assigned the welfare of the poor to communal and estate jurisdictions in a 1552 Polizeyordnung. ${ }^{20}$ It was a double-edged sovereign assertion of, first, the royal state's prerogative to oversee collective welfare and, second, of doing so not by actual welfare arrangements but by compelling local jurisdictions (legally still under members of the Stände, the Estates) to carry out, strictly with local means, central directives implementing a Heimatprizip for all subjects that guaranteed a "legal domicile" either in one's place of birth or acquired by way of communally recognized acceptance. ${ }^{21}$ This system of centrally issued but unfunded mandates functioned for a considerable length of time with religious, guild, and private foundations carrying much of the weight. When, at times, that arrangement failed, local jurisdictions were increasingly permitted to restrict their responsibility only to those who could effectively claim birthright. They were allowed, in addition, to issue begging permits to the rest. ${ }^{22}$

The limits of this solution appear in a 1727 census for Upper Austria. Conducted after a period of general economic improvement, though one attenuated by a decline in the local linen trade, this census found over 25,000 vagrants, mostly women and children-altogether about 8 percent of the province's population..$^{23}$ The local communes' resistance to claims for assistance made by indigent would-be "natives" (Einheimische) had, by this time, produced a countermovement of ad hoc unburdening in which communes forcibly conveyed those deemed ineligible for local assistance to external jurisdictions. Schub, the term used for these practices, derives from schieben: to push, to shove, which implies movement by force (hence abschieben). It was language adopted by the royal government's renewed attempt to assert its prerogatives in this area by regulating forcible removals in a royal Patent of April 13, 1724, titled "Abschaffung fremder Bettler" (getting rid of foreign beggars). ${ }^{24}$ This codification put in place a command structure by which

\footnotetext{
${ }^{18}$ See Rebel, "Reimagining the oikos."

${ }^{19}$ Wendelin, "Schub," 231-32, 340-43. Wendelin specifically rejects the perspective on perpetrators and victims offered in Robert Jütte, "Bettelschübe in der frühen Neuzeit," in Ausweisung und Deportation. Formen der Zwangsmigration in der Geschichte, ed. Andreas Gestrich, Gerhard Hirschfeld, and Holger Sonnabend (Stuttgart: Stuttgarter Beiträge zur historischen Migrationsforschung, 1995), 61-72.

${ }^{20}$ Wendelin, "Schub," 181; Bruckmüller, Sozialgeschichte, 269.

${ }^{21}$ Wendelin, "Schub," 181.

${ }^{22}$ Ibid., 181-82; Bruckmüller, Sozialgeschichte, 270.

${ }^{23}$ Siegfried Haider, Geschichte Oberösterreichs (Munich: Oldenbourg, 1987), 256.

${ }^{24}$ See Franz Tobias Herzog, Vollständige Sammlung der Gesetze über das Schubwesen im Kaiserthume Österreich (Vienna: Heubner, 1835), 1-26. This article refers to the copy available at Oberösterreichisches Landesarchiv (hereafter OöLA, G483/1). Another document useful for this research is Franz Lorenzoni, Österreichisches Heimatgesetz (Linz: Oberösterreichischer Bauernbund, 1925). Lorenzoni, an official with the provincial government in Linz, provided texts
} 
local peasants and other subjects legally under the authority of members of the Estates could be commandeered to carry out the Schub orders of the provincial representatives of the central government. The new regulation drew a distinction between, on one hand, the so-called Particularschub, which was basically an extension of existing local communal and landed estates' practices, all now governed by state rules, and, on the other hand, a large-scale biannual winter and summer Hauptschub taking the form of public, albeit "secretly" organized, wholesale roundups for short- and long-distance transfers, carried out by state and Estates authorities working in tandem. The changes and adjustments in these mandates and practices, as recorded by Franz Tobias Herzog, disclose not only the governing concepts in this emerging police apparatus, but also the figural languages and the intrinsically contradictory burdens it imposed on those who had to suffer under and perform in it. ${ }^{25}$

In Herzog's compilation, the 1724 Patent is followed by another 424 Schub-related decrees, decisions, orders, interpretations, and so on, whose frequency had grown rapidly by the early nineteenth century. Between 1724 and 1800, 106 laws and regulations appeared, whereas 390 were enacted in the much shorter period from 1800 to $1834 .{ }^{26}$ Such growth did not reflect an evolving sophistication but was, for the most part, a sped-up recycling of repetitions of yet earlier repetitions still not being obeyed, with occasional rescinding of earlier mandates. The general impression this documentary record imparts is that of a bricolage of practices in which the degree of "control" depended on who was in command at the moment, and in whichgiven the absence of funding for these mandates - no questions of budgetary or administrative accountability could arise. There were modifications, but the ensemble of authorities, practices, and languages that made up the Schub remained generally the same throughout the eighteenth and nineteenth centuries. In some respects, they remain the same to this day. ${ }^{27}$

The implicitly comparative aspect in all this is that, while homelessness appears to be a universal phenomenon, the poverty and exposure that inherently characterize it arise from different circumstances. The different responses to homeless people, ranging from ameliorative to managerialcoercive, also have their specific histories. In English usage, for example, where there were analogs in forced military impressments and convict transports, there was nothing like the quality of the threats appearing adjacent to Schub in Herzog's compilation. ${ }^{28}$ These range from "Abschaffung" (getting rid of) to "Ausrottung" (extermination) and "Vertilgung" (eradication). Anyone drawn into the system was reduced, in a usage that survives to this day, to the generic common denominator Schübling, someone who has been forfeited ("verfallen") to the Schub. ${ }^{29}$

The most significant distinction among different treatments of the homeless is arguably the length of residence required to achieve the right to claim membership and welfare in one's "native" community, a right known in much of German-speaking Europe as Heimatrecht. Compared to the more realistic English practice of a yearlong residence as the basic qualifier, it was in Austria the notorious "Decennium"- the requirement that one prove an uninterrupted ten-year residence in a community before being eligible to receive assistance-that governed

and commentary for the Upper Austrian peasant union on the precedents of the administrative courts (what he calls Spruchpraxis) following the constitutional revisions of Heimatrecht in 1863, 1896, and 1925. On Herzog, see note 25.

${ }^{25}$ Herzog, Vollständige Sammlung der Gesetze. Herzog was one of the most prominent of several civil servant-scholars who compiled and commented on rulings, a task necessary for any system of interactive codifications. These individuals tended to specialize in particular areas of laws and regulations (Herzog's other publications included collections of and comments on bankruptcy law and marriage law, published respectively in 1824 and 1829) and to serve particular constituencies.

${ }^{26}$ Herzog, Vollständige Sammlung der Gesetze, ix-xxvi, 67.

${ }^{27}$ The main sources from Herzog used for this article, besides the 1724 Patent, are the Styrian "Schubnormale" of 1750 , the Bohemian "Security and Schub Patent" of 1751, and Maria Theresa's "Security and Schub Patent" of 1751.

${ }^{28}$ Herzog, Vollständige Sammlung der Gesetze.

${ }^{29}$ Wendelin, "Schub," 271, 287. 
the entire process. ${ }^{30}$ Not only could this condition rarely be met by the poor, dispossessed, and disabled, but there were also, as we will explore later, institutions and practices actively at work in the employment and life-course patterns of one-year-contract farm laborers (Gesinde), as well as of day laborers, artisan journeymen, and others, that would deny them the means of ever meeting the terms of the Decennium. It is this detail in the institutional construction of the Austrian state's welfare design that separated it from practices elsewhere governed by a more realistic sense of what was humanly possible. Heimat, when paired with the Decennium, created a fiction of inclusion and membership that could, in actual practice, apply only to a few: to incumbents on peasant leases, to owners of guild-recognized workshops, inns, and merchant houses and their immediate heirs, and, on sufferance, to those who could be employed locally. ${ }^{31}$ The unemployed (and unemployable) dispossessed, meanwhile, joined the generations of the unpropertied and entered lives of agricultural and craft labor, civilian or military servitude, inevitable unemployment, itinerant opportunism, and vagabondage — all the while dodging the Schub police, with the latter acting, in perhaps its true assignment, as a kind of social boundary police.

The foundational mandate in the 1724 Patent, often repeated in subsequent orders, was to restore social peace by "cleansing" the countryside of "aggressive beggars" and "roaming Gsind." 32 The central institutions for accomplishing this were the annual summer and winter Hauptschub events. These were large-scale, secretly organized ("surprise") impositions of states of siege and raids, conducted by drafted peasant subjects, their servants, and other quasi-militarized civilian personnel under the command of the Schub police and, on occasion, of district military units. They were authorized to occupy churches and other places of refuge, close all Danube crossings, lock gates and doorways, patrol little-travelled escape routes, and conduct house-to-house searches from cellar to attic. They were also to collect homeless persons who had previously been arrested, detained in, and freed from holding stations, to comb the countryside "gathering up" (aufgreifen) strays, to arrest gangs of homeless in their squats and hiding places, and even to find those who had been sheltered illegally (as well as to punish those who had offered such refuge). Adjustments were possible, both to strengthen the constitutional foundations of some practices of the Schub and to displace costs further downward. For example, the more advanced absolutist constructions of Joseph II, whose "modernization" sought to strengthen the web of state offices and practices against local autonomy, connected Schub practices to the Robot (labor services) Patent of 1785 to give the Schub police greater powers to command uncompensated services from members of civil society, including servants, carters with draught animals and wagons, medical doctors, as well as village welfare (and other) officials. ${ }^{33}$

The Schubsystem was an altogether formidable apparatus for maintaining a surveillance society, signifying a distinct shift from an earlier, localized, "as needed" quality of the Schub, toward a pervasive, centrally directed, and aggressively intrusive vigilance that learned to adjust to local differences. The Hauptschub seems not to have worked well in rural areas, but became a way to disperse

\footnotetext{
${ }^{30}$ Herzog, Vollständige Sammlung der Gesetze, 44-46, 91. Even if gained, the right could be lost after a prolonged absence, usually of two years (see pp. 30, 65, 255). The possession of Heimatrecht in a commune appeared as the foundational prerequisite for Austrian citizenship and remained a key provision in the Austrian constitution of 1929. See Felix Ermacora, Österreichische Bundesverfassungsgesetze (Stuttgart: Philipp Reclam, 1967), 50-51.

${ }^{31}$ There were attempts to modify and temper the Decennium over time, but it remained in force and was invoked on a case-by-case basis into the early twentieth century. See Lorenzoni, Heimatgesetz, 53, 60-61, 67-68.

${ }^{32}$ Herzog, Vollständige Sammlung der Gesetze, 1-2; Gsind is a colloquial form of Gesinde (servants) but can also refer to Gesindel (rabble) (ways to read this double entendre are also discussed later). The lists of actual persons targeted for the Schub in Herzog's collection of rules include - appearing almost as if at the framers' whim - "the poor," tramps (Landstreicher), thieves, robber gangs, soldiers, quacks, pilgrims, wandering clerics, idlers, gypsies, peddlers, musicians, students, Jews with an "expired tolerance," prostitutes, foreigners, and journeymen.

${ }^{33}$ Herzog, Vollständige Sammlung der Gesetze, 357-58.
} 
the urban homeless back to the countryside. In certain Viennese quarters, the once semiannual roundup became, by 1817, a biweekly affair-even as it was falling into disuse in the countryside at large. There the more ad hoc Particularschub, organized by reciprocal agreements among the local authorities, all but displaced the larger, centrally directed sweeps. ${ }^{34}$ Even though the orders came from the royal authorities, the actual practices remained in the hands of locals who could act with the full original spectrum of authorizations. Their authorized actions included, at one end of the spectrum, routine everyday "stopping" (anhalten) of people deemed "foreign" ( fremd), as well as of the disabled, destitute, and possibly criminal—checking personal papers, then possibly making arrests for having no papers, or for idleness, unauthorized begging, an inability to account for oneself, and so on. At the other end of the spectrum were the periodic, organized manhunts on various scales, which empowered those involved to dispense summary justice ("Standrecht") against presumed criminals and to place any and all vagrants under arrest. ${ }^{35}$

Two classes emerged from this perpetually active roundup. There were those who were found to be the "truly and worthy poor," who could effectively prove their connection to a Heimat or at least to a place of long-term residence, a "Domicil," whose residents might be willing (or could be forced) to accept them. ${ }^{36}$ In contrast to those deemed valuable and connectable, there were others who were not so valued, who were spoken about in violent and exclusionary, even deadly, language. The unmistakable intention, beginning with the 1724 Patent, was the "extermination" (Ausrottung) of "pernicious rabble" (schädliche Gesinde).

It is significant that the usage of the word Gesinde in these rulings is unstable. Derived from a medieval term for a lord's military entourage, it had evolved to become the term for a civilian labor force working alongside a farmer. Yet, the addition of a diminutive "l" turns Gesinde around completely to signify its opposite, Gesindel: an unattached "rabble." It is apparent, moreover, that both terms appeared interchangeably in official regulations to signify, in all cases, "rabble." The official conflation of "servants" and "rabble" throughout the corpus of regulatory texts points to an important dimension of Heimatrecht: one could claim residence in the household of one's employer, but unemployment and the seeking of work elsewhere put one at risk of being netted in the Schub. This unavoidable duplexity put constant pressure on farm, craft, and day laborers, whose status and treatment as civil persons depended on moment-to-moment rulings based on usages that encouraged a perpetual slide from Gesinde to Gesindel.

The rub in the Decennium-based surveillance state was that the system was very good at arresting people, at drawing them in. But once it had them, it did not have adequate or realistic notions about the outflow, i.e., about what to do with those for whom it had, in effect, assumed responsibility. The imperative to return people "ad locum nativitatis," to a legally provable place of origin, was a utopian fiction. ${ }^{37}$ It imagined that such places would be discoverable by a police bureaucracy of arresting agents, researchers, and letter- and inquiry-writers, along with road escorts capable of finding these places; it then involved leading people there and then getting those who were there already to accept and take care of people who could not be "tolerated" (the term toleriert appears throughout) elsewhere. ${ }^{38}$ The delusional design inside the Heimat utopia became unavoidably evident when, on the larger diplomatic stage, both neighboring and distant states, including

\footnotetext{
${ }^{34}$ Ibid., 4-5, 201, 288.

${ }^{35}$ Ibid., $9,14$.

${ }^{36}$ Ibid., 5.

${ }^{37}$ Ibid., 66 .

${ }^{38}$ This fiction held even when any connection or awareness of "home" was long lost—as in the case of a Württemberg soldier who, after serving in the Austrian military for thirty-three years (followed by eight years in irons at fortification labor as punishment for desertion) was, upon release, placed "on the road" (instradiert) to find a home, though none could have existed in Bohemia, Styria, or Upper Austria. See Ibid., 326.
} 
Bavaria, Prussia, Saxony, and the bishopric of Speyer, among others, sued Austrian authorities for conveying people across their borders without having determined with certainty the provable destinations of those individuals. ${ }^{39}$ Herzog's collection includes frequently repeated orders from the top that every officer at every level of the system not send anyone anywhere without having verified an ascribed or claimed Heimat. These instructions conjure up a nightmare (within sight of Franz Kafka's imaginary) of an infinite regression of impossible verifications, of an endless circulation of letters of inquiry, in which those receiving them have no interest in answering them truthfully, if at all.

The detainees, supplied with Schubpässe (conveyance passports) that identified them as Schüblinge, had to be maintained at the expense of the apprehending authorities or of those into whose jurisdiction they had been delivered. This burden was the incentive for all participating authorities simply to keep such individuals walking, to pass them on to some further Heimat intended down the road. In this regard one has to say that Wendelin's argument - that there were no perpetrators in a system allegedly driven only by an unfathomable will-for-the-state-is clearly mistaken. ${ }^{40}$ The imposition of deliberately unfunded mandates inside the command structure and the actions of the Schub police executing these regulations demonstrate where the lines of agency ran.

An 1820 Chancellery decree illustrates how such practices were formalized: it unburdened the communities where arrests had been made but burdened instead "those dominions and communities" where the arrestees "had once lived the longest" and which were thus "obliged by law to supply employment or maintenance (Beschäftigung oder Versorgung) of such vagabonds until we have discovered where they were born or they had found refuge under the Decennium." 41 The latter was a sham ethical commitment when, at the center of this mandate- and indeed of the Schubsystem as a whole - resided a legal void enacted by scores of bureaucrats corresponding with adversary communities to ascertain and confirm arrestees' birth and life-course information, and forcing, until that search succeeded, actual communities to maintain those who had been moved there.

"Longest residence" was not testable since it required a measurement of record, such as parish registers that, in many cases, were not maintained with sufficient continuity or coherence, or that were simply unavailable. The caprice permitted to the Schub police was evident in amendments that allowed "longest residence" to be only a "contributing" and not a "determining" consideration, as well as in the granting of permission to the police to inquire of arrestees unable to remember where they had lived the longest what the biggest town was that they could remember-and then to send them there. ${ }^{42}$ The search for Heimat was an unenforceable order and its consequence was to eject people into the effectual attrition figured by this legal void. It was in everyone's interest simply to keep people walking, moving in a controlled manner, confined to the open road, to la strada (and hence "instradiert"), for theoretically interminable - and therefore physically terminal-journeys of daily ten- to twelve-hour, daily marches on foot, often in mountainous terrain, in all weather, sometimes with shackles, sometimes through the night (to be less visible), and with no viable destination in sight or even imaginable.

\section{The Experience of the Schub}

There were many dispossessed, and children of the dispossessed, who had virtually no hope of ever establishing residency under the Decennium and who, therefore, made up a permanent army of

\footnotetext{
${ }^{39}$ Ibid., 69, 184-85, 290, 334-35.

${ }^{40}$ Wendelin, "Schub," 231-32, 340-43.

${ }^{41}$ Herzog, Vollständige Sammlung der Gesetze, 235-36 (also 71, 94).

${ }^{42}$ Ibid., 217, 347.
} 
domestically contained but literally stateless persons. One of the chief sources of disconnection were the one- or, at best, two-year, nonrenewable contracts under which the Gesinde were hired. ${ }^{43}$ It was the rotation of laborers, of men, women, and children, through ever more distant communities of employers - always with the danger of not receiving a commendation, which itself could become a reason to be remanded to the Schub- that set up workers for unemployed homelessness. ${ }^{44}$ Those caught up in the dragnets who were deemed able-bodied (for the time being) were selected and turned over to the military press gangs, to the workhouses or other labor assignments, from which not even children were exempt. ${ }^{45}$ Children experienced special versions of the legal void not only because of the abusive and corrosive treatment they received, but also because their potentially parentless status demonstrated yet another facet of the system's inherent self-contradictions. Parentless children were required to be placed on the road to find their parents' birthplaces; children of homeless mothers could not claim the town where they had been born as their birthplace; children born to women already "on the road" could not claim any town as birthplace and, as a result, none was obliged to take them in. ${ }^{46}$ In other words, by enforcing the presumption that everyone had to have a Heimat somewhere, the regulators created contingencies that denied that premise.

The system's fantasies about destinations concealed the terminal places-never once mentioned as such in Herzog's collection of regulations - that were required by the practices of the system. It is only in the archives of the noble and ecclesiastical estates and of the towns' administrations where one finds out what happened when those enforcing the rules of Heimat ran out of options. There were local assignments to "shelters" for those incapable of further movement on the road: Herberg, Hörberg, Herweg are some of the designations one finds, for example, in Schub-administration documents from the Upper Austrian estate Steyr. ${ }^{47}$ These were rough hospices-literally "in the straw," as the contemporary phrase put it - in barns and outbuildings, even in caves, usually without any kind of medical care and with only minimal food provided until death.

In a system without compensation, the local authorities, forced to accept the terminally unmovable, juggled the poor laws to compensate those willing to allow their barns to be used for those destined for "the straw." Individuals thus deposited were given the official communal status of "Einleger" (boarder). The Steyr records reveal that estate and town administrations assessed on local leaseholds an amount that would go into a fund to compensate those who agreed to take in an Einleger "for care." For this they received an exemption from the poor levy and a care stipend ("Verpflegungsgeld"). Account registers for the period 1778-1781, when Steyr's Steinbach department $(A m t)$ administered 301 houses, show an annual budget for this purpose fluctuating around 350 gulden (fl), with about thirty individual householders receiving, on average, about $4 \mathrm{fl}$ a year with some, for reasons that are not clear, getting larger sums (e.g., 12fl or 20fl). The register for September 26, 1780, compiled by Georg Stigler, an administrator at Amt Forsthueb on the Enns, shows that taking in an Einleger for even only part of the year gained virtually complete poor-levy relief for a householder, and that a considerable number took advantage of this break. In Stigler's accounts, of 127 assessed houses, a surprisingly large proportion (80) had taken in at least one Einleger (or more: the number of persons is not recorded)

\footnotetext{
${ }^{43}$ On such labor contract limitations, see the household reconstitution studies in Michael Mitterauer, HistorischAnthropologische Familienforschung (Vienna: Böhlau, 1990), 257-87.

${ }^{44}$ Herzog, Vollständige Sammlung der Gesetze, 416-17.

${ }^{45}$ Ibid., 90, 103, 235 (on press gangs), and 50-51, 57, 71, 198 (on workhouses or other labor assignments).

${ }^{46}$ Ibid., 26, 59-60.

${ }^{47}$ Steyr was a significant transfer point on the Schub roads between Upper and Lower Austria and Styria. See OöLA, Herrschafts Steyr, Box 349IV, "Schubwesen, 1740-1819," fasz. 603 \#6 (1740) and fasz. 573 \#12 (1768) (hereafter Ö̈LA, Schubwesen 1740 and OöLA, Schubwesen 1768, respectively).
} 
for periods of eight weeks to a year. When multiplied across hundreds of such jurisdictions, this number gives a sense of the size of the population arriving at the terminal points in the system. A typical formula from Steyr's Amt Haussa reads: "Matheus Brunnerguetl had a beggar for five weeks who then died." The assessment against Brunnerguetl's house of $2 \mathrm{fl} 44 \mathrm{kr}$ (euzer) was reduced to $10 \mathrm{kr}$, which indicates that providing a sheltered death for even a short time was rewarded with a significant welfare-tax reduction. The number of recorded Einleger deaths in these departmental accounts-occurring in 20 to 30 percent of the houses that had accepted Einleger-appears low, but this is not surprising given that the practical design of the Schub was for people to disappear in unremarked, anonymous deaths. ${ }^{48}$

For those not yet near death, the selections of the various authorities for moving or not moving people, for including or excluding them from assistance, replicated, at the local level, the diplomatic and legal sparring among states over the accepting or returning of Schüblinge across borders and jurisdictions. It is instructive to read, for example, the letters, orders, affidavits, and similar documents that circulated in 1740 between the authorities of the Steyr estate and the abbey St. Florian (located between Linz and Steyr) concerning the case of Maria Hueber, a servant who had been impregnated and abandoned by her employer. Maria walked to Steyr, carrying her child and the "proof" of her baptismal certificate, but Steyr's authorities refused to accept her and sent her back. ${ }^{49}$ The high-level correspondence among Wolf Misstelmaister ( juris doctor and chief accountant for Steyr), Carl Huebmer (chief magistrate for the abbey), and the commissioners of the chief of provincial security in Linz stretched from August through November. It consisted of assertions, denials, accusations, and counteraccusations, in which Huebmer attempted to impose a fine on Misstelmaister for dereliction of duty. The case was finally resolved when the house in which Maria had been born was perceived to be a marginal shack for processing flax ("vor Jahren abgekommene Haarstube") whose jurisdictional status was uncertain and therefore not imposing any burden on Steyr. The fact that being born in such a house would deny anyone a claim on Heimatrecht was yet another instance in which the foundational presumption that everyone had a legally recognizable place of birth failed to reflect reality. In the end, the legal fiction that resolved Maria's case was that the house did belong to ecclesiastical estate Steyr; this let the secular estate Steyr off the hook.

What was happening to Maria and her baby during these several months of official dickering is not recorded. She was evidently placed on the road between destinations - for example, when the Steyr authorities once again returned her to St. Florian with the message that "even if they send her twenty times," they would never accept her "in care." The fate of Maria and her child remains unknown, as does that of most other Schüblinge who appear in these files-only simply to disappear. Maria does not turn up in the Steyr account ledgers for the 1740 Schub year, which we will now examine. ${ }^{50}$ Her absence (and possibly that of others) there suggests that the total number of persons appearing in the Schub files is an undercount that provides only a partial sample of who was in the system. Despite this flaw, the data in the files enable some understanding of the processes and languages of selection that operated at the communal and estate administrative levels.

In a distinction maintained in subsequent years, the fifty-five "cases" (involving 105 persons) in the 1740 file are of two kinds, corresponding to the two classes created and managed by the system. The class of "worthy poor" emerges from a type of agreement among the estates and towns under Steyr's sway: Markt Hall, the abbey Gleink, the estates Leonstein and Losensteinleithen, and

\footnotetext{
${ }^{48}$ OöLA, Herrschaftsarchiv Steyr, Box 356, fasz. 575 \#6, "Armenverpflegung, 1778-1781."

${ }^{49}$ OöLA, Herschaft Steyr, Box 356 VI/11, "Vagabunden."

${ }^{50}$ OöLA, Schubwesen 1740.
} 


\begin{tabular}{|c|c|c|c|c|c|c|c|c|}
\hline 1740 & ASSEKUR. & RECIPI6. & TOTAL & MALES & FEMALES & NO GENDER & CHILDREN & TOTAL \\
\hline JAN. & 2 & - & 2 & 2 & 1 & - & - & 3 \\
\hline FEB. & - & - & - & - & - & - & - & - \\
\hline MAR. & 1 & 4 & 5 & - & 6 & - & 1 & 7 \\
\hline APRIL & 2 & 3 & 5 & 3 & 5 & - & 2 & 10 \\
\hline MAY & 1 & - & 1 & 1 & - & - & - & 1 \\
\hline JUNE & 6 & 1 & 7 & 4 & 10 & - & 4 & 18 \\
\hline JULY & 2 & 6 & 8 & 5 & 6 & - & 2 & 13 \\
\hline AUG. & 1 & 9 & 10 & 10 & 4 & 12 & 1 & 27 \\
\hline SEPT. & 6 & 1 & 7 & 5 & 5 & - & 3 & 13 \\
\hline OCT. & - & 1 & 1 & 1 & - & - & - & 1 \\
\hline NOV. & 1 & 1 & 2 & 3 & - & - & - & 3 \\
\hline DEC. & - & 7 & 7 & 4 & 4 & 1 & - & 9 \\
\hline TOTAL & 22 & 33 & 55 & 38 & 41 & 13 & 13 & 105 \\
\hline
\end{tabular}

Figure 1. The Schub Year. Estate Steyr 1740.

others. This agreement, called an Assekuration or Versicherung, i.e., an assurance, was a means by which the various authorities engaged in a kind of localized administrative diplomacy (analogous to a military practice, noted by Herzog, by which regiments carried on a previously agreed-upon "cartelized" exchange of deserters). ${ }^{51}$ The authorities of estate Leonstein thus gave Steyr an "assurance" on March 25, 1740, that they would take back in care "at any time" Maria Rothenhuber, a baker's wife (not a widow), and her child (neither age recorded) if she could not maintain herself at Steyr. In all such cases - including, as well, permissions for persons to move or marry outside a Heimat jurisdiction, with a prior commitment to accept them back (Abschiedt, Entlaßschein, Heirathskonsens) — were individually tailored agreements that did add, in several instances, the phrase "without further Schub order" (ohne weitere Schubverordnung) to make it clear that the persons in question were to be kept out of a system perceived throughout as a debasing, honor-diminishing institution. ${ }^{52}$

In sharp contrast to the class of those protected by such mutual assurances was the class of those who were unquestionably locked into the system and were being walked or carted from place to place under documents called Schubpässe, Schubrecipiße, or most frequently, simply Recipiße, i.e., processing "receipts" recording the arrivals and further transports of persons. We thus read a Recipi $\beta$ dated March 18, 1740, from estate Losensteinleithen, a Schub authority to the north of Steyr and a crossing point into Lower Austria, according to which two women (age and status unrecorded) were being returned to Steyr because they had been sent without the proper document ("ohne einen ordentlichen Schubzettel") into Lower Austria. ${ }^{53}$

That the persons appearing in this second category of files constituted a separate population, subject to a process of attrition by depersonalization and physical exhaustion in preparation for their eventual disappearance, comes into focus in the table in Fig. 1, whose data is drawn from the 1740 files. This table illustrates aspects of this process and allows a comparison of people being drawn into one or the other classification. It also provides a sense of the time of year, of the moments in the annual labor cycle, that most affected each of the two classes. The columns to the left of the divide in the table show the number of assurances (Assekutationen) and receipts (Recipiße), the columns to the right the number of people actually covered by these documents.

It is worth noting that no age distinctions were drawn and that there were considerably fewer assurances than receipts overall. Two assurances were granted in January in the aftermath of the

\footnotetext{
${ }^{51}$ Herzog, Vollständige Sammlung der Gesetze, 246.

${ }^{52}$ On the shame or humiliation (Schmach) of the Schub, see Ibid., 208, 345.

${ }^{53}$ OöLA, Herrschaft Steyr, Schubwesen, Box 349IV, fasz. 573.
} 
previous year's Hauptschub and before the new hiring cycle. Little happened in January and February because this was the end of the labor year, which began anew in March, when the annual contracts of the Gesinde, the servant farm laborers, began. The termination of one-year work contracts occurred on February 2, Candlemas, and the annual "musical chairs" of employment negotiations took place during that month, in the dead cold of winter, itself contributing to the attrition of the migrant homeless looking for work. This was followed in March and April by several Schub receipts for people who had likely lost the employment game, but also by a few further assurances to accept responsibility for three others-likely potential workers. The increase in assurances in June may be seen as a prelude to the summer Hauptschub (already in full practice in 1740) as a way to shelter specific people from that process.

As the table in Fig. 1 shows, the Hauptschub dominated the period from June to August, with nine receipts in the last month alone. More assurances were granted in its immediate aftermath, and nothing of significance happened on that side of the process for the remainder of the year. The year closed in December with the winter Hauptschub, which saw another seven receipts issued for nine persons put on the road. That there were twice as many persons as documents in the entire file is a result of occasional groups of people being marched under a single document. The number of men and women in this particular Schub population was roughly equal, but it is worth noting that 14 percent of the adults had no gender description, a clear sign of the depersonalization at work even at this early stage of the system's development.

In the next Steyr Schub file that has survived (from 1768), the two classes of documents were not intermingled, as in 1740, but now recorded separately. ${ }^{54}$ Without resorting to a table, one finds some demographic elements here of the divide between those receiving assurances and those being passed on with receipts by looking at the distribution of the ninety-two persons for whom gendered designations exist. Fifteen men, twenty women, and eleven children - forty-six persons altogetherfound the safety of an assurance under reciprocal agreements. They grouped themselves into twelve couples and eleven single individuals, of whom three were women with children. On the other side, among those who were moved under receipts— a number that also, curiously, adds up to forty-six - there were only one couple and forty-two single individuals, two of whom were women with one child each. Only two persons in the entire file were identified by age, and they were both on the transported side. One was a twenty-nine-year-old day laborer being returned to the previous Schub station at Molln. The other, aged twenty-six and without occupation, had been arrested for begging near Linz and was being returned to Steyr. The authorities' selections for protection clearly favored families with children, as well as several individuals with labor potential. Those who were selected for the Schub were almost universally single, unattached, unemployed, and possibly unemployable.

The 1740 file provides a clue for recognizing how people were made into receipt-bearing human packages being moved from place to place. Thirteen people (12 percent of the total) appear without name, gender, or other indicators of identity, and without any discernible origin or home destination. Twelve of the thirteen turned up during the summer Hauptschub: they included one group of "ten poor persons" on a single receipt sent to Hall from Steyr, and another of two unidentified persons under a receipt from Losensteinleithen (on the Schub road from points south) for further conveyance (Beförderung) by way of the Schub (schubmässig), without stated destination. The third instance is that of a completely disembodied entity traveling, in effect, as only a sealed letter from the Steyr accounting office (Rentamt) to Leonstein.

At the bottom of the Schubsystem was a process of never-ending movement that could effect an attrition of identity, a devolution toward a loss of human markers once one had been "put on the

\footnotetext{
${ }^{54}$ OöLA, Schubwesen 1768.
} 
road" (instradiert). ${ }^{55}$ That these practices had not changed a great deal a century later is evident when we examine Schub registers of the city Freistadt, located northeast of Linz, for the period 1844-1847. ${ }^{56}$ Out of the 125 persons who appear in that period as designated for movement, there were 4 adults who were not gendered; the rest reveal a significant preponderance of men over women (95 to 23), with only three children. The overall picture remains bleak. Even though, in this instance, more attention was being paid to age and gender, only 45 had any kind of occupational or personal status designation, and 68, i.e., more than half, were without any Heimat destination. Of the "origins" that were noted, many were broadly geographical (e.g., Croatia, Poland, Carinthia, Lombardy, etc.) and practically meaningless. The actual further destinations of persons thus identified were not any sort of Heimat or even a "tolerance"-but simply the open road itself.

\section{Normal Violence}

Barely identified by name and age and otherwise without qualities, these were people being moved until they succumbed to the rigors of exposure, were shunted into "the straw," or escaped into rough living to fade away. An option for this last course of action was to join more or less organized groups of the homeless, recognized, in turn, as "gangs," and hunted down to be literally exterminated by the Schub police acting under the command of local estate-owning authorities. Before examining this last stop on the road, one needs to understand more clearly that it was the Schub's everyday practice of violence that created agents with attitudes hardened by experience toward implementing fatal attritions of bodies and identities. Examining both who and what methods and languages enabled these dire tasks allows for an appreciation of the terrors and agonies of the system's victims, as well as of the effectual brutalization of the functionaries - the social boundary police - tasked to labor in the system.

Reaching into the Freistadt files to discover what happened to any particular person caught up in the system, we find a Schubpass, dated December 13, 1844, of an "imbecilic mute woman" (blödsinnige stume Weibsperson) named Marie Wiesinger. ${ }^{57}$ Estimated to be forty years old, of middling stature, black hair cut off to abate vermin ("wegen Ungeziefer abgeschnitten"), she was arrested on August 11, 1844, for begging and for "wandering about without a destination" (bestimmungsloses Herumziehen). An attached note, dated August 16 at Freistadt, indicates that she had no known birthplace and that she was infested "with every sort of vermin." What happened to her during the autumn following her arrest is not recorded, but we find her, still with no known destination, put on the road on December 13 (with all that that implies in terms of weather) on the way toward the estate Weinberg, a major Schub station for the area north of the Danube. We can follow her itinerary: she arrived at Weinberg, about a $10 \mathrm{~km}$ walk from Freistadt, on December 14. That same day she was marched another $13-15 \mathrm{~km}$ to the estate Haus, located near Pregarten, and from there (still on December 14!), was sent off to walk another 10-12 km south to the estate Schwertberg, where she arrived the next day. Her next trek took her another 10-12 km to Zellhof, where, on December 16, a court doctor named Alois Fiertner attested that she was of weak physical condition, had bad feet, and was to be transported by horse cart. Her next stop was the station at Ruttenstein, another $10 \mathrm{~km}$ to the northeast, where she arrived on December 17, only to be transported on the same day for a long $18-20 \mathrm{~km}$ journey to the estate Harrachstal. From there she was returned to the road, still on December 17, on the way toward Freistadt, another $12 \mathrm{~km}$ away. She had been walked and carted almost

\footnotetext{
${ }^{55}$ Herzog, Vollständige Sammlung der Gesetze, 121.

${ }^{56}$ Ö̈LA, Stadtarchiv Freistadt, Hs. 1091, "Schubprotokolle, 1844-1852."

${ }^{57}$ OöLA, Stadtarchiv Freistadt, Box 460, "Schubpässe."
} 
continuously during three nights and days, in a circle of about $90 \mathrm{~km}$ in circumference. There is no record of her arrival in Freistadt. She simply disappears.

One of the persistent complaints noted in the ordinances was that Schüblinge were not being taken to proper destinations, but were being released in the next town or abandoned "on the open road" (auffreier Straße). ${ }^{58}$ Marie Wiesinger's life likely ended this way. The legal self-contradictions and duplexities at the heart of the system authorized obvious abuses and irregularities. Some were noted in the ordinances and singled out for oft-repeated prohibitions, but never with even the most elementary corrections or sanctions. The prevalence of such violations of stated protocol suggests that the disappearances of persons who were put "on the road" was a tacitly accepted practice. ${ }^{59}$

The sequence that carried people from family dispossession (or from having been born to propertyless parents) to Gesinde labor, and from there to migrant unemployment, finally made many a part of the rabble, the Gesindel - to "having come down to the Schub" (aufden Schub gekommen), as the formula went. This simultaneously social and figural devolution was accompanied by insidious mechanisms and prescribed practices, whose publicly stated purpose claimed to be benign, yet contained incentives for and manifestations of disobedience, petty yet fatal corruption, and malevolence. These small violences constituted an unending pressure toward further social disconnection, exploitation of weakness, mounting fatigue, and, finally, elimination. There were regulations requiring that people not be walked aimlessly back and forth. ${ }^{60}$ Yet, over time, authorities increasingly allowed people to be shunted back and forth because their papers were not in order, or because their places of birth were not recognizable as legal destinations. The kind of journey forced on Marie Wiesinger became commonplace once forced marches without definite destinations became the norm. ${ }^{61}$ To keep people moving by confiscating the documents they had, or by forcing them to buy the documents back, kept them from ever making a claim of Heimatrechteven as their movement was purported to be a search for the place where such a claim could be made. ${ }^{62}$

Persons in occupations ranking below the local authorities and their police agents were drawn into auxiliary, expediting roles for these deadly practices. The road escorts, drafted from the subject population and anonymous in the documents, managed a Schübling's daily food allotment of $6 \mathrm{kr} .{ }^{63}$ When the regulations, even as they complain frequently about the unfit quality of these escorts, yet insist throughout that escort labor be done without compensation under robot rules, then the disincentive to feed persons for the full amount of even this meager stipend seems overwhelming. ${ }^{64}$ There was, at the operational moments when people were actually being forcibly moved, an insistent, prohibited-yet-authorized brutality, an invitation to violence: not only to apply various intensities of debilitating restraints (leg chains, mouth gags, etc.), as well as beatings, brandings, and worse, but also to provide less than life-sustaining bread and water rations ("schmale Atzung"). Taken together, these were the instruments of attrition intended to speed the passage of people through the system- - hence the interesting designation, often repeated, of Durchschübling, of being "pushed though." 65

\footnotetext{
${ }^{58}$ Herzog, Vollständige Sammlung der Gesetze, 154.

${ }^{59}$ Ibid., 121, 303.

${ }^{60}$ Ibid., 130.

${ }^{61}$ Wendelin's dismissive incredulity at the similar forced marches he found in the archive is an example of the currently "correct" attitude of denial with respect to the experience of victims required of any official or academic discourse on the Schub. See Wendelin, "Schub und Heimatrecht," 282, 289.

${ }^{62}$ Herzog, Vollständige Sammlung der Gesetze, 312-13. Journeymen in particular were subject to this kind of abuse.

${ }^{63}$ Ibid., 313, 378.

${ }^{64}$ Ibid., 69, 139, 174, 324, 357-58.

${ }^{65}$ Ibid., 71, 77, 89.
} 
Empowered to oversee and intervene in these everyday practices were unpaid medical doctors on call at each stopping station along the system. They were required to examine the Schüblinge paraded past them in order to select out those who could no longer be movedand would thus be placed in local "care" until well enough to be put back on the road, even if no recovery could be expected. Working under the direction of local magistrates who coordinated the "tolerance" agreements and the extraditions by Schub, the doctors had no incentive, no option, to keep people against the wishes of these authorities. It is again the duplexity of a system constructed around an unacknowledged legal contradiction about forcing someone to return to a fictitious Heimat that permitted doctors the option of ordering a cart (Vorspann) from a subject peasant for carrying those who could no longer walk to the next station. ${ }^{66}$ In other words, and in flat contradiction of yet other ordinances that required persons to be taken off the Schub if they were ill, medical authorities could sign off on putting even the severely ill and dying on horse carts, to let a jolting uphill and downhill journey on rutted roads take care of the rest. ${ }^{67}$ There are indications, moreover, that Schüblinge were subject to medical procedures such as bleeding, which, no doubt, further weakened them. ${ }^{68}$ The plaintive noises from the central authorities, pointing to the many deaths in the system and exhorting doctors to take better care-but never specifying sanctions for malpractices-only confirm the violent double-sidedness in action inside these simultaneously social and rhetorical operations and role performances. ${ }^{69}$

\section{Gypsies}

There is one more historical figure to explore concerning those who escaped the interlocking mechanisms of Heimatrecht and Schubsystem. Such escapees often became, if only for selfdefense, members of large and small "gangs," of a greatly feared organized underclass perceived to be (and no doubt was) living in rough places at the fringes of an exclusionist Heimat, threatening society (according to the ordinances) with organized begging, extortion, thefts, house invasions, and worse. The dominant name attached to such persons in the documents is Gesindel (rabble), but one also finds, often in the same breath, Zigeuner, or gypsies.

Looking from the perspective of such adjacent linguistic usages in the Schub regulations and practices, it is doubtful that language about Zigeuner referred exclusively to what is currently perceived to be an ethnic designation as Sinti and Roma. ${ }^{70}$ In the Schub sources of the eighteenth century, we rarely find the class "Zigeuner" by itself. It appears almost always in company with other kinds of outcasts, specifically with those identified as occupying the rhetorically unstable ground between Gesinde (farm labor) and Gesindel (rabble), often expressed as Gesind, without either ending to the word. As early as the 1724 Patent, Schub authorities were authorized to act on reports of sightings of "gypsy- and robber-Gsind," of "gangs of thieves" (Diebsrotten)

\footnotetext{
${ }^{66}$ Ibid., 206, 329, 391. For a ruling that those who were terminally ill ("siechenhaft") could thus still be placed in the Schub, see p. 190.

${ }^{67}$ Ibid., 194, 280-81.

${ }^{68}$ For the experience of an all-but-toothless, "deaf-mute male" in his mid-thirties of unknown origin, arrested by Thalgau authorities in May 1840, see OöLA, Herrschaftsarchiv Freistadt, "Steckbriefe," Box 284.

${ }^{69}$ Herzog, Vollständige Sammlung der Gesetze, 115-16, 355.

${ }^{70}$ This accords with some of the approaches developed among historians working on Roma and Sinti history in Europe; see Wim Willems, "Ethnicity as a Death Trap: The History of Gypsy Studies," in Gypsies and Other Itinerant Groups: A SocioHistorical Approach, ed. Leo Lucassen, Wim Willems, and Annemarie Cottaar (New York: St. Martin's Press, 1998); Diane Tong, ed., Gypsies: An Interdisciplinary Reader (New York: Garland, 1998). For a revealing and rich Austrian historical ethnography, see Claudia Mayerhofer, Dorfzigeuner. Kultur und Geschichte der Burgenland Roma von der Ersten Republik bis zur Gegenwart (Vienna: Picus, 1987).
} 
alongside "Zigeunergesind." There was talk of the local countryside being "penetrated" by a gypsy gang ("Zigeunerrotte"), which then appears later in the same ordinance as "vagrant Gesindel."71

This article's final theme concerns this intermingling of figural speech in the Schub regulations (and not simply in ordinary speech), creating what amounted to an indeterminate ethnicity for the homeless. The legal mingling of so-called gypsies with vagrant servant labor enabled the system's actors to target, for officially organized murder, groups of people that included people falling under both designations, i.e., the dispossessed of the peasantry itself organized in mobile "gypsy" gangs of the homeless.

The authorities' repeated use, in this connection, of the term Rotte (gang or pack), ${ }^{72}$ alerts us to the verb ausrotten (to exterminate), a term that also appeared frequently in the regulations and even in the title of a Bohemian ordinance of 1750 specifically in connection with unattached persons. ${ }^{73}$ By the nineteenth century, ausrotten was being slowly replaced in the regulations by less directly murderous terms such as "removal" (Beseitigung), "getting rid of" (hinweg- or abschaffen), or "rendering harmless" (unschädlichmachen).$^{74}$ But the violence implied by these apparently more temperate terms is clear: to brand anyone with the epithet "gypsy" marked that person for possible extermination, euphemized over time as removal or elimination. ${ }^{75}$

Deeply buried in Central European institutional memory is evidence of deadly manhunts of "gypsies" sanctioned by the authorities. When a Zigeunergesindel has been spotted, instructs the 1724 Patent, local authorities were to organize in utmost secrecy ("in höchster Stille"), without delay and without waiting for higher authorization, a force supplied by several neighboring jurisdictions, including the local military, to arrest these persons and turn them over to the Schub police. Evidence that these combined authorities exceeded that mandate is contained in a revealing record of one such gypsy hunt, conducted under the authority of the chief administrator (Pfleger) of the estate Weinberg, a major administrative jurisdiction close to Freistadt in the area between Linz and the Bohemian border. In a series of letters written between 1713 and 1716, the region's various estate managers discussed exterminating Zigeuner and recorded one such coordinated hunt in late May 1715 to "catch and exterminate loose robbers." 76 The first of two reports records that the gypsies ("Zügeiner") were caught in a "Rott of thirty head" whose members, except for three, were exterminated. In a second, related report, the "escaped gypsy rabble" (solvierte Zigeunergesündel) was encountered in two groups: eleven of the first group were "massacred" (massacriert), with three escapees; the second group, already mentioned in the other report, was "exterminated" (ausgerottet).

There is a rhetorically interesting coda to this successful "hunt" in which the thin linguistic screen separating "gypsy" and "gypsy rabble" (Zigeunergesindel) from Gesinde, the rural labor force, breaks down. This is found in some of the official correspondence organizing additional such hunts in the immediate aftermath of the first one. In response to reports about "rampant gypsies" (grassierende Zigeuner: the adjective is linguistically related to epidemics and infestation), Wilhelm von Thürheim, the provincial chief and owner of the estate Weinberg, circulated a letter on June 9, 1716, calling for a "raid on an agreed-upon day and hour to be kept as secret as possible." He requested authorities "to assist in the extermination (austilgen) of loose

\footnotetext{
${ }^{71}$ Herzog, Vollständige Sammlung der Gesetze, 11, 31, 117 (also 86).

${ }^{72} \mathrm{Ibid} ., 31$. Rotte is another ambiguous term with resonances in military usage as a "troop," shading into identifying military units without allegiance or controls; it refers to wild pigs in the language of hunters. Both usages are clearly connected with the manhunt dimensions of the word in a Schub context.

${ }^{73}$ Ibid., 31.

${ }^{74}$ Ibid., 167, 206, 236, 372.

${ }^{75}$ Mayerhofer, Dorfzigeuner, 32-34.

${ }^{76}$ OöLA, Herrschaft Weinberg, Box 301 A/2, "Zigeuner, 1636-1784."
} 
Gsündt." 77 This language makes clear that the target of eradication was not gypsies, but some configuration of "loosed," or released, or dismissed Gesinde(l). ${ }^{78}$

The intentions of this indeterminate identification were repeated in further disseminations of this circular. The possibly unconscious transposition of attention from gypsies to unemployed laborers is even more evident in correspondence that organized a 1784 raid on a gang of "several head" of "gypsies and dismissed servants" (abgedankte Diener). The Schub police and border authorities who carried out these raids participated in a linguistic as well as a social figuration, which, under the sign of extermination, conflated gypsies with vagrant, unemployed workers, i.e., with those who were, in the wider social formation, the necessarily dispossessed among the peasantry. ${ }^{79}$ By means of a linguistic shift, the identifying markers of the dispossessed were linked to a branded ethnicity subject to official pursuit and extermination. The social figure, visible on the road, of the homeless being walked to death had acquired a fatal metonymic capacity that, on one hand, points forward to and contains the genocide of Sinti and Roma in the Holocaust, as at least partial fulfillment of this exterminist prefiguration. ${ }^{80}$ On the other hand, the gypsy hunts by the Schub authorities were a figure in action that served to displace awareness away from those socially destructive mechanisms by which members of a social class could be forced to take on an ethnicity already under sentence of death-mechanisms that continued to operate as well in the Nazi state as they had in the ancienrégime Austrian empire.

Not even the Nazi state's exploitation of the figure of Heimat could call into question the delusional cult of it that Theodor Adorno would recognize throughout his later work as a repression of the Auschwitz trajectory. He perceived a metonymic historicity in the German existentialists' naïve version of it, in the bourgeois, white-collar frisson of an inner homelessness at the very heart of shelteredness, which Adorno identified as the fear of unemployment under capitalism. ${ }^{81}$ The figural narrative runs deeper than that, however. Before capitalism, Heimat and the fear of its loss, of living without ever being able to attain it - except perhaps by demonstrating what counted as sufficient discipline to serve in its deadly police apparatus - indexed various modalities of dispossession, unemployment (even before capitalism), and social disconnection. The fear in this system was substantial, its workings visible in the underside of Heimat, in the degrading languages and deadly practices adopted toward those being excluded from the protections available in the absolutist-corporatist state.

The University of Arizona

\footnotetext{
${ }^{77}$ Ibid.

${ }^{78}$ It is hard to resist pointing out that this exterministist language (and its conversion into state commands) resonates with similar contemporary formulas in Maria Theresa's efforts to eradicate sparrows. Her so-called sparrow patents (Spatzenpatente) of 1744, 1751-53, and 1762 (see OöLA, Patentsammlung Krackowizer), which set forth quotas for the delivery and disposal of sparrows' heads and threatened investigations of those who did not deliver, made liberal use of the term Ausrottung — as did her discourses on beggars.

${ }^{79}$ The association is compounded when we learn that gypsies were not allowed to become lodgers ("Inleute, " i.e., freely contracting day laborers or artisans), but could only be employed as Gesinde, as laborers on annual contract. By the 1840s, persons against whom the epithet "gypsy" had been used could successfully contest that usage as calumny by demonstrating that they had a residence; conversely, this meant that if they did not have residence, the epithet could stick. See Mayerhofer, Dorfzigeuner, 28, 34-36, 43.

${ }^{80}$ Sybil Milton has recognized the gypsies' entanglement in Holocaust pre-figrations from as late as Weimar and the early 1930s. See her summary, "Holocaust: The Gypsies," in Century of Genocide: Eyewitness Accounts and Critical Views, ed. Samuel Totten, William Parsons, and Israel Charny (New York: Garland, 1997), 161-202; idem, "Antechamber to Birkenau: The Zigeunerlager after 1933," in The Holocaust and History, ed. Michael Berenbaum and Abraham J. Peck (Bloomington: Indiana University Press, 1998), 384-400.

${ }^{81}$ Theodor Adorno, The Jargon of Authenticity, trans. Knut Tarnowski and Frederick Will (Evanston, Il: Northwestern University Press, 1973), 26-27, 33-34. For a contrasting perspective, see Peter Blickle, Heimat: A Critical Theory of the German Homeland (Rochester, NY: Camden House, 2002).
} 